\title{
Systemic Therapy for Male Breast Cancer
}

\author{
Ali Jad Abdelwahab Yousef* \\ General Surgery and Anesthesia Department, Mutah University, Jordan
}

Submission: January 28, 2020; Published: February 18, 2020

"Correspondence Author: Ali Jad Abdelwahab Yousef, Full-Time Lecturer, General Surgery and Anesthesia Department, Faculty of Medicine, Mutah University, Karak- Jordan

\begin{abstract}
Male breast cancer is a rare malignancy accounting for $<1 \%$ of all cancers in men and $<1 \%$ of all breast cancers. Most of the cases are advanced stage ductal invasive carcinomas and express hormone receptors in the great majority and are less likely to over-express HER2-neu. Treatment includes locoregional methods such as surgery and radiotherapy, and systemic treatment mainly with hormonal therapy and, to a lesser extent, trastuzumab and chemotherapy as second lines. Nonetheless, the optimal treatment for male breast cancer is not known due to lack of prospective randomized trials. In this review systemic therapy for male breast cancer is discussed in the neoadjuvant and adjuvant settings, with insight into the treatment of advanced disease.
\end{abstract}

Keywords: Male breast cancer; Hormonal therapy; Tamoxifen; Chemotherapy; Trastuzumab

\section{Introduction}

Till now there are no prospective randomized trials supporting specific treatment guidelines in male breast cancer. Almost all treatment strategies that have been adopted in male breast cancer are based upon data resulting from female breast cancer studies. The treatment of male breast cancer includes two objectives: treatment of local disease which includes surgery and radiotherapy, and systemic treatment. Systemic therapy for male breast cancer includes hormonal therapy, chemotherapy, and immunotherapy. Adjuvant systemic treatment is used $\mathrm{t}$ to eradicate occult disease or treat advanced disease, while neoadjuvant treatment certain specific indications. Unfortunately, the data regarding systemic therapy for male breast cancer are limited because it has been primarily evaluated in case reports and small case series [1].

\section{Adjuvant Hormonal Therapy}

The selective anti estrogen tamoxifen is the standard of care for adjuvant hormonal treatment in male breast cancer. Tamoxifen improves survival rates in estrogen receptor-positive female breast carcinoma, and since male breast cancer is estrogen receptor-positive in about $90 \%$ of cases, adjuvant tamoxifen therapy in men is presumed to be an essential part of treatment. The treatment entails $20 \mathrm{mg}$ of oral tamoxifen daily for 5 years [2]. No randomized clinical trials have assessed the role of adjuvant tamoxifen in male breast cancer, but several small retrospective studies have documented better disease- free and overall survival rates with adjuvant tamoxifen treatment than without tamoxifen $[3,4]$. Taken together, the data support the value of adjuvant tamoxifen for hormone-receptor positive male breast cancer. The role of adjuvant aromatase inhibitors in male breast cancer has not been determined but it is used when there are contraindications to tamoxifen or when there is metastatic disease. It is not known whether a gonadotropin releasing hormone agonist (GNRH-a) or orchidectomy is needed when an aromatase inhibitor is prescribed to achieve complete estrogenic suppression.

\section{Adjuvant Chemotherapy}

The roleforadjuvantchemotherapy in male breast cancer is less well established due to the rarity of the disease and the difficulty of conducting randomized controlled trials, but the existing data do suggest specially reduced risk of relapse [5,6]. Great caution should be experienced when giving chemotherapeutics due to older age at presentation and the presence of significant co morbidities. The same guidelines applied to female breast cancer are used so that chemotherapy should be used in the absence or doubt about endocrine-responsiveness, and the taxanes may be considered when lymph nodes are involved.

\section{Adjuvant Trastuzumab}

No data are available about the role of adjuvant trastuzumab in male breast cancer. However, since very substantial therapeutic benefit is observed after adjuvant trastuzumab in women with 
HER2-positive breast cancer, adjuvant trastuzumab should be considered for men with high-risk, HER2- positive breast cancer according to patients' and tumor characteristics, following female breast cancer guidelines.

\section{Neoadjuvant Therapies}

The indications for neoadjuvant therapies are the presence of an ulcerated tumor, fixation of the tumor to the surrounding tissues, and advanced lymph node involvement [7].

\section{Treatment of Advanced Disease}

Hormonal therapy is the mainstay for treatment of metastatic male breast cancer. Before the introduction of tamoxifen, hormonal balance was achieved by surgical procedures including orchidectomy, adrenalectomy, or hypophysectomy, which produced a positive response in $55-80 \%$ of the cases, depending on the procedure performed [8]. None the less; these procedures were not attractive because they were irreversible, psychologically disturbing, and associated with significant surgical morbidity and mortality. Nowadays these methods have been replaced by various types of additive hormone treatment, the most important being tamoxifen, which produces a good response in about $50 \%$ of cases [9]. Other hormones used included androgens, antiandrogens, progestins, corticosteroids, aminoglutethimide and high doses of estrogens. Response rates ranged from $32 \%$ to $75 \%$, according to the drug used [10].

Complete response rates had been reported with LH-RH analogues, with or without antiandrogens [11]. Anastrozole and letrozole achieved prolonged stability and showed objective responses, and these treatments are likely to be a subject for further investigation in the future $[12,13]$. Systemic chemotherapy is usually reserved for second-line or third-line treatment since most patients will respond favorably to hormonal treatment which produces superior response rates when compared to chemotherapy [14]. Since most cases of male breast cancer present at an older age, this in itself should not be considered an absolute contraindication to chemotherapy. Treatment choice $s$ depends upon the clinical and biological characteristics of the tumor. At the present time, chemotherapy is administered to hormone-refractory disease, to young men and to cases of aggressive tumors, for example those with visceral metastases, and for significant palliation [15]. Response rates varied from $13 \%$ for single-agent fluorouracil to $67 \%$ for fluorouracil, doxorubicin, and cyclophosphamide (FAC) [9].

Although up to one third of male breast cancers are shown by immunohistochemistry to over express HER2, gene amplification is rare. Only case reports exist about trastuzumab use in metastatic male breast cancer [16]. For male breast cancers over expressing HER2/neu, trastuzumab should be given according to data from female breast cancer guidelines both in the adjuvant and in the metastatic settings [17].

\section{References}

1. Margaria E, Chiusa L, Ferrari L, Dal Canton O, Pich A et al. (2000) Therapy and survival in male breast carcinoma: a retrospective analysis of 50 cases. Oncol Rep 7(5): 1035-1039.

2. Giordano SH, Perkins GH, Broglio K, Garcia SG, Middleton LP, et al. (2005) Adjuvant systemic therapy for male breast cancer. Cancer 104(11): 235-264.

3. Zhou FF, Xia LP, Wang X, Guo GF, Rong YM, Qiu HJ, et al. (2010) Analysis of prognostic factors in male breast cancer: a report of 72 cases from a single institution. Chin J Cancer 29(2): 184-188.

4. Fogh S, Hirsch AE, Langmead JP, Goldberg SI, Rosenberg CL, et al. (2011) Use of tamoxifen with postsurgical irradiation may improve survival in estrogen and progesterone receptor-positive male breast cancer. Clin Breast Cancer 11(1): 39-45.

5. Yildirim E, Berberoglu U (1998) Male breast cancer: a 22-year experience. Eur J Surg Oncol 24(6): 548-552.

6. Early Breast Cancer Trialists' Collaborative Group (EBCTCG) (2005) Effects of chemotherapy and hormonal therapy for early breast cancer on recurrence and 15-year survival: an overview of the randomized trials. Lancet 365(9472): 1687-1717.

7. Czene K, Bergqvist J, Hall P, Bergh J (2007) How to treat male breast cancer. Breast 16: S147-54.

8. Crichlow RW, Galt SW (1990) Male breast cancer. Surg Clin North Am 70(5): 1165-1177.

9. Jaiyesimi IA, Buzdar AU, Sahin AA, Ross MA et al. (1992) Carcinoma of the male breast. Ann Internal Med 117(9): 771-777.

10. Fentiman IS, Fourquet A, Hortobagyi GN (2006) Male breast cancer. Lancet 367(9510): 595-604.

11. Labrie F, Dupont A, Belanger A, Lacourcière Y, Béland L, et al. (1990) Complete response to combination therapy with an LHRH agonist and flutamide in metastatic male breast cancer: a case report. Clin Invest Med 13(5): 275-278.

12. Giordano SH, Valero V, Buzdar AU, Hortobagyi GN (2002) Efficacy of anastrozole in male breast cancer. Am J Clin Oncol 25(3): 235-237.

13. Zabolotny BP, Zalai CV, Meterissian SH (2005) Successful use of letrozole in male breast cancer: a case report and review of hormonal therapy for male breast cancer. J Surg Oncol 90(1): 26-30.

14. Lopez M, Di Lauro L, Lazzaro B, Papaldo P (1985) Hormonal treatment of disseminated male breast cancer. Oncology 42(6): 345-349.

15. Kraybill WG, Kaufman R, Kinne D (1981) Treatment of advanced male breast cancer. Cancer 47(9): 2185-2189.

16. Rudlowski C, Rath W, Becker A, et al. (2001) Trastuzumab and breast cancer. N Engl J Med 345(13): 995-998.

17. Romond EH, Perez EA, Bryant J, Suman VJ, Geyer CE Jr, et al. (2005) Trastuzumab plus adjuvant chemotherapy for operable HER2-positive breast cancer. N Engl J Med 353: 1673-1684. 
This work is licensed under Creative Commons Attribution 4.0 License DOI: 10.19080/CTOIJ.2020.15.555921

\section{Your next submission with Juniper Publishers will reach you the below assets}

- Quality Editorial service

- Swift Peer Review

- Reprints availability

- E-prints Service

- Manuscript Podcast for convenient understanding

- Global attainment for your research

- Manuscript accessibility in different formats

( Pdf, E-pub, Full Text, Audio)

- Unceasing customer service

Track the below URL for one-step submission https://juniperpublishers.com/online-submission.php 